\title{
Immunogenicity of Foot-and-Mouth Disease Virus Dendrimer Peptides: Need for a T-Cell Epitope and Ability to Elicit Heterotypic Responses
}

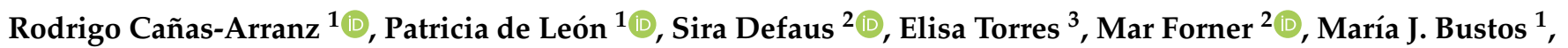 \\ David Andreu ${ }^{2}$, Esther Blanco ${ }^{3}$ (D) and Francisco Sobrino ${ }^{1, *(D)}$ \\ 1 Centro de Biología Molecular "Severo Ochoa" (CSIC-UAM), 28049 Madrid, Spain; \\ rcannas@cbm.csic.es (R.C.-A.); pdeleon@cbm.csic.es (P.d.L.); mjbustos@cbm.csic.es (M.J.B.) \\ 2 Departament de Ciències Experimentals i de la Salut (DCEXS-UPF), 08003 Barcelona, Spain; \\ sira.defaus@upf.edu (S.D.); fornermar@gmail.com (M.F.); david.andreu@upf.edu (D.A.) \\ 3 Centro de Investigación en Sanidad Animal (CISA-INIA), 28130 Valdeolmos, Spain; elisa.torres@inia.es (E.T.); \\ blanco@inia.es (E.B.) \\ * Correspondence: fsobrino@cbm.csic.es
}

check for updates

Citation: Cañas-Arranz, R.; de León,

P.; Defaus, S.; Torres, E.; Forner, M.;

Bustos, M.J.; Andreu, D.; Blanco, E.;

Sobrino, F. Immunogenicity of

Foot-and-Mouth Disease Virus

Dendrimer Peptides: Need for a

T-Cell Epitope and Ability to Elicit

Heterotypic Responses. Molecules

2021, 26, 4714. https://doi.org/

$10.3390 /$ molecules26164714

Academic Editors:

José Vidal-Gancedo and

Vega Lloveras

Received: 12 July 2021

Accepted: 1 August 2021

Published: 4 August 2021

Publisher's Note: MDPI stays neutral with regard to jurisdictional claims in published maps and institutional affiliations.

Copyright: (c) 2021 by the authors. Licensee MDPI, Basel, Switzerland. This article is an open access article distributed under the terms and conditions of the Creative Commons Attribution (CC BY) license (https:/ / creativecommons.org/licenses/by/ $4.0 /)$.

\begin{abstract}
An approach based on a dendrimer display of B- and T-cell epitopes relevant for antibody induction has been shown to be effective as a foot-and-mouth disease (FMD) vaccine. $\mathrm{B}_{2} \mathrm{~T}$ dendrimers combining two copies of the major FMD virus (FMDV) type O B-cell epitope (capsid proteinVP1 (140-158)) covalently linked to a heterotypic T-cell epitope from non-structural protein 3A (21-35), henceforth $\mathrm{B}_{2} \mathrm{~T}-3 \mathrm{~A}$, has previously been shown to elicit high neutralizing antibody $(\mathrm{nAb})$ titers and IFN- $\gamma$-producing cells in both mice and pigs. Here, we provide evidence that the B- and T-cell epitopes need to be tethered to a single molecular platform for successful T-cell help, leading to efficient $\mathrm{nAb}$ induction in mice. In addition, mice immunized with a non-covalent mixture of $\mathrm{B}_{2} \mathrm{~T}-3 \mathrm{~A}$ dendrimers containing the B-cell epitopes of FMDV types $\mathrm{O}$ and $\mathrm{C}$ induced similarly high $\mathrm{nAb}$ levels against both serotypes, opening the way for a multivalent vaccine platform against a variety of serologically different FMDVs. These findings are relevant for the design of vaccine strategies based on B- and T-cell epitope combinations.
\end{abstract}

Keywords: FMDV; peptide vaccine; dendrimer

\section{Introduction}

Foot-and-mouth disease (FMD) is a highly transmissible and economically devastating animal disease [1-3] for which vaccination and strict regulations on animal movements and markets are the only means for control [4]. The current OIE-approved vaccines consist of the chemically inactivated whole virus emulsified with different adjuvants (reviewed in [5]). In an outbreak in regions where vaccination is not implemented, massive culling of susceptible animals has been the main measure to control the spread of the disease, leading to large economic losses as well as ethical controversy [6]. Conventional polyvalent FMDV vaccines, containing two or more inactivated viruses from different serotypes, aim to match the potentially circulating viruses and the epidemiological status of each region/country. These vaccines have demonstrated their success in eliciting protective immunity against the disease in endemic countries. Nevertheless, inactivated vaccines continue to pose enough disadvantages to have prompted the adoption of non-vaccination (stamping out) policies in the EU and Western countries (reviewed in [7]), making the development of alternative, safer and effective vaccines an important issue.

Subunit vaccines based on well-characterized immunogenic determinants (not the entire pathogen) have emerged as an attractive alternative to conventional formulations. In particular, this strategy includes fully synthetic peptide vaccines that mimic well-defined B- and T-cell epitopes from the infectious agent and induce protection against it [8]. Linear 
peptides have been associated with low immunogenicity and partial protection [9]. Nevertheless, there are several strategies to address such issues. We have made significant progress towards dendrimeric peptide-based FMD vaccine candidates based on a lysine core that comprises both a continuous B-cell epitope capable of inducing $\mathrm{nAb}$ (corresponding to the G-H loop in FMDV VP1 capsid protein), and T-cell epitopes widely evoking CD4+ responses, thus presenting solid and protective responses in natural hosts (reviewed in [10]). These dendrimer constructs, particularly those encompassing two copies of the $\mathrm{B}$-cell epitope and one of the T-cell epitope $\left(\mathrm{B}_{2} \mathrm{~T}\right)$, can afford levels of protection against FMDV challenge when administered to pigs similar to those induced by conventional vaccines [8]. The initial results showed that the inclusion and specific orientation of the T-cell epitope (i.e., residues 21-35 of FMDV 3A protein) modulates the immunogenicity of the dendrimer. The T-3A epitope was selected from PBMCs of outbred pigs sequentially infected with two FMDVs of different serotypes in order to identify "promiscuous" FMDV T-cell epitopes, and was shown to be capable of stimulating in vitro lymphoproliferation [11]. These responses were abolished by monoclonal antibodies against both class I and class II, with inhibition being higher for class II. The ability of T-3A to stimulate T-cells was confirmed by its ability to specifically induce nAbs in PBMCs from pigs cultured in vitro. Regarding the functional characterization of T-3A, besides its ability to elicit and stimulate in vitro IFN $\gamma$-producing cells (demonstrated by ELISPOT), we have additional evidence from intracellular cytokine staining (ICS) of its ability to induce antigen-specific T-cells (memory T-helper cells) (see below). Furthermore, immunization of pigs with $B_{2}$, i.e., a $\mathrm{B}_{2} \mathrm{~T}$-like construct lacking the T-3A epitope, failed to induce nAbs despite the production of FMDV-specific antibodies. Additional data providing further support for T-3A as a T-cell epitope are beyond the scope of this manuscript. T-3A has been successfully incorporated as a specific FMDV T-cell epitope in other subunit vaccine prototypes [12,13].

In general, it has been shown that juxtaposition of B- and T-cell epitopes within a single molecule is necessary for effective T-cell help (mediated by cognate interactions), leading to efficient induction of specific antibodies against B-cell epitopes [14-16] Thus, elucidation of this immunogenic requirement for dendrimer peptides is relevant for the design of future vaccine candidates based on the combination of different B- and T-cell epitopes.

\section{Materials and Methods}

\subsection{Peptides}

The preparation of B-cell epitopes from FMDV O-UKG 11/01, VP1 (residues 140-158), T-cell epitope $3 \mathrm{~A}$ (residues 21-35), and $\mathrm{B}_{2}$ peptide and $\mathrm{B}_{2} \mathrm{~T}$-dendrimers $\mathrm{B}_{2} \mathrm{~T}-3 \mathrm{~A}$ from Type $\mathrm{C}\left(\mathrm{B}_{2} \mathrm{~T}-3 \mathrm{~A}-\mathrm{C}\right)$ and $\mathrm{B}_{2} \mathrm{~T}-3 \mathrm{~A}$ from Type $\mathrm{O}\left(\mathrm{B}_{2} \mathrm{~T}-3 \mathrm{~A}-\mathrm{O}\right)$, named $\mathrm{B}_{2} \mathrm{~T}-3 \mathrm{~A}$, has been described previously $[8,17,18]$.

\subsection{Viruses}

The FMDV stock O/UK/11/01 (The Pirbright Institute, UK) was amplified in IBRS-2 cells and the Type C CS8-c1 virus [19] was amplified in BHK-21 cells.

\subsection{Animals}

Groups of 8 or 10 5-to-6-week-old outbred female mice (Swiss ICR-CD1, Envigo) were maintained under standard housing conditions at the CBMSO animal facility. Mice were immunized subcutaneously, twice, on days 0 and 20 or 21 with $100 \mu \mathrm{g}$ of each peptide emulsified in Montanide ISA 50V2 (Seppic-France) and euthanized on day 40 or 42 . Blood samples were collected on days $0,20 / 21$ and $40 / 42$ post-immunization (pi).

\subsection{Virus Neutralization Test (VNT)}

Neutralization assays were performed as previously described [8]. Briefly, serial 2-fold dilutions of each serum sample were incubated with 100 infection units- $50 \%$ tissue culture infective doses $\left(\mathrm{TCID}_{50}\right)$ —of FMDV O-UKG 11/01 or CS8-c1 virus for $1 \mathrm{~h}$ at $37^{\circ} \mathrm{C}$. Next, a cell suspension of IBRS-2 cells in DMEM was added and the plates were incubated for 
$72 \mathrm{~h}$. End-point titers were calculated as the reciprocal of the final serum dilution that neutralized $100 \mathrm{TCID}_{50}$ of homologous FMDV in $50 \%$ of the wells.

\subsection{Detection of Anti-FMDV Antibodies by ELISA}

Specific antibodies were assayed by ELISA as described [8] using plates coated with peptide B $(1 \mu \mathrm{g})$ that were incubated with 3-fold dilutions of serum and detected using HRP-conjugated protein A. Plates were read at $450 \mathrm{~nm}$ and titers expressed as the reciprocal of the last serum dilution, given an absorbance range of 2 standard deviations above the background (serum on day 0 ) plus $2 \mathrm{SD}$.

\subsection{Statistical Analyses}

Differences among peptide-immunized groups in FMDV antibody titers were analyzed using Student's t-test. Values are cited in the text as means \pm SD. All $p$ values are two-sided, and $p$ values $<0.05$ were considered significant. Statistical analyses were conducted using GraphPad Prism Software 5.0.

\section{Results and Discussion}

\subsection{Intramolecular Combination of B-and T-Cell Epitopes Is Required for Induction of} FMDV-Specific Antibodies

We previously showed that immunization of Swiss mice with $\mathrm{B}_{2} \mathrm{~T}$ elicits specific IFN- $\gamma$-secreting T-cells in response to $\mathrm{B}_{2} \mathrm{~T}$ and the T-peptide alone but not the B-peptide, supporting the recognition of T3A as a T-cell by these mice [20]. To study whether the T-3A T-cell epitope needs to be included in the same construct with the B-cell peptide to efficiently elicit FMDV antibodies, groups of 10 mice were immunized and boosted (day 20 pi) with $0.1 \mathrm{~g} /$ dose of $\mathrm{B}_{2} \mathrm{~T}-3 \mathrm{~A}, \mathrm{~B}_{2}+\mathrm{T}-3 \mathrm{~A}, \mathrm{~B}_{2}$ or T-3A. In the group immunized with $\mathrm{B}_{2} \mathrm{~T}-3 \mathrm{~A}$, most mice developed ELISA-detectable Ab titers upon the first injection $\left(1.2 \pm 0.6 \log _{10}\right)$, which were boosted by a second dose ( 9 of 10 mice; $1.5 \pm 0.5 \log _{10}$, Figure $\left.1 \mathrm{~A}, \mathrm{~B}\right)$. Consistent with the lack of T-cell epitopes, the antibody response was significantly lower in animals immunized with $\mathrm{B}_{2}$ alone $(0.5 \pm 0.1 \log 10)$, with only a single mouse showing titers above 1 upon boosting. No antibody response was detected in animals immunized with T$3 \mathrm{~A}$ alone. Interestingly, when both epitopes were given separately $\left(\mathrm{B}_{2}+\mathrm{T}-3 \mathrm{~A}\right)$, the antibody response was significantly lower than with $\mathrm{B}_{2} \mathrm{~T}-3 \mathrm{~A}$, with ELISA titers above 1 for only two mice on day $42\left(0.5 \pm 0.6 \log _{10}\right)$ (Figure $\left.1 \mathrm{~A}, \mathrm{~B}\right)$. These results correlated well with neutralizing antibody titers (VNT), which were only consistently found after the second dose in mice immunized with $\mathrm{B}_{2} \mathrm{~T}-3 \mathrm{~A}\left(1.7 \pm 0.6 \log _{10}\right)$ (Figure $\left.1 \mathrm{C}\right)$.

These results support the need for covalently linking both B- (i.e., $\mathrm{B}_{2}$ ) and T-cell epitopes (i.e., T-3A) within a single molecular entity to provide T-cell help and high titers of anti-FMDV nAbs. This is in tune with previous results showing that T-cell-dependent B-cell activation relies on the inclusion of both epitopes in the same molecular platform, as an efficient antibody response occurred when both epitope types targeted the same APC.

\subsection{A Mixture of $B_{2} T-3 A$ Dendrimers Harboring B-Cell Peptides from Different FMDV Serotypes} Elicits Similar Titers of Type-Specific Neutralizing Antibodies

Current polyvalent FMD vaccines incorporate inactivated viruses from different FMDV serotypes. To explore the capability of our dendrimer platform to allow heterotypic immunization, we assessed the neutralizing antibodies elicited by a mixture of two $\mathrm{B}_{2} \mathrm{~T}-3 \mathrm{~A}$ constructs with different $B$-cell epitopes. To this end, groups of eight mice were immunized twice with: (i) an equimolar mixture of $\mathrm{B}_{2} \mathrm{~T}-3 \mathrm{~A}-\mathrm{O}+\mathrm{B}_{2} \mathrm{~T}-3 \mathrm{~A}-\mathrm{C}$ containing, respectively, the B-cell epitope motifs from Type O FMDV O/UK/11/2001 and Type C CS8-c1 isolate; (ii) $\mathrm{B}_{2} \mathrm{~T}-3 \mathrm{~A}$ from Type $\mathrm{C}\left(\mathrm{B}_{2} \mathrm{~T}-3 \mathrm{~A}-\mathrm{C}\right)$ or (iii) $\mathrm{B}_{2} \mathrm{~T}-3 \mathrm{~A}$ from Type $\mathrm{O}\left(\mathrm{B}_{2} \mathrm{~T}-3 \mathrm{~A}-\mathrm{O}\right)$ (Figure 2). 
A

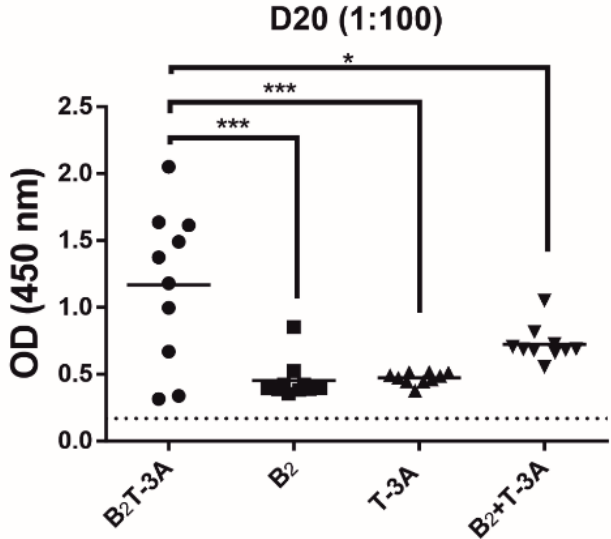

B

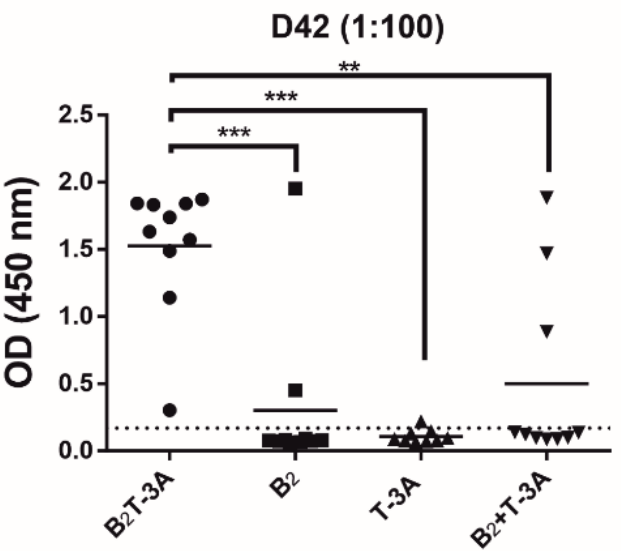

C

VNT D42

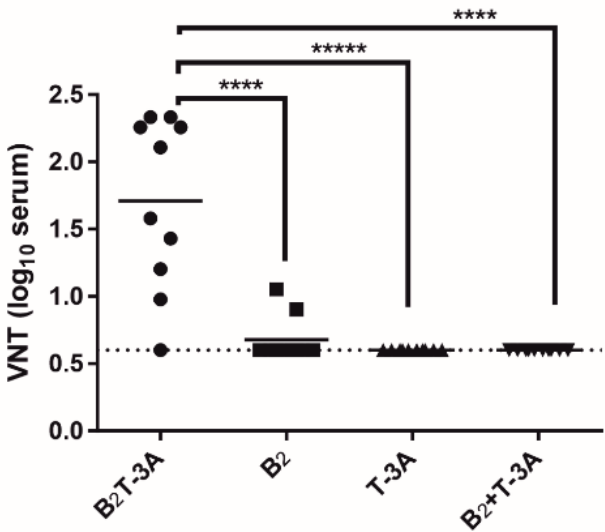

Figure 1. Incorporation of both B- and T-cell epitopes is required for efficient induction of FMDVspecific antibodies by FMDV dendrimers. Antibodies in sera from groups of animals $(n=10$ Swiss mice) immunized twice (on days 0 and 20) with $0.1 \mathrm{mg} /$ dose of $\mathrm{B}_{2} \mathrm{~T}-3 \mathrm{~A}, \mathrm{~B}_{2}+\mathrm{T}-3 \mathrm{~A}, \mathrm{~B}_{2}$ or T-3A. ELISA titers against $B_{2}$ peptide at 20 days pi (A) and 42 days pi (B). Virus-neutralizing antibody titers (VNT) on day 42 pi against $\mathrm{O} / \mathrm{UK} / 11 / 2001$, a type O FMDV isolate whose sequence is homologous to those of the $B_{2}$ and T-3A peptides $(C)$. Each point represents the mean of a triplicate assay for each mouse. Dotted lines indicate the detection limit of the assay. Values are expressed as the reciprocal $\log _{10}$ of the serum dilution that neutralized $100 \mathrm{TCID}_{50}$ of FMDV. Statistically significant differences are indicated by asterisks $\left(^{*}\right)$ for $p<0.05,\left(^{* *}\right)$ for $p<0.01,\left({ }^{* * *}\right)$ for $p<0.001,\left({ }^{* * *}\right)$ for $p<0.0001$, and $(* * * *)$ for $p<0.00001$ 
A

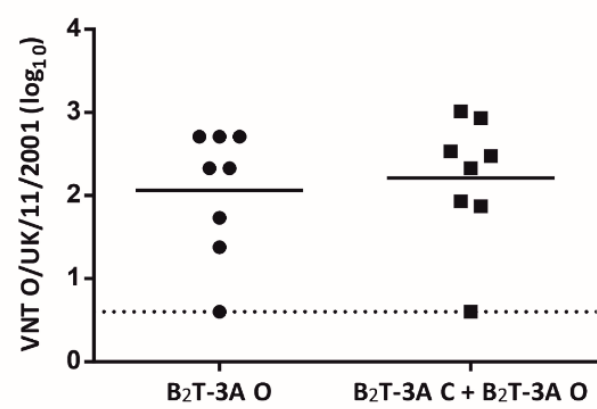

B

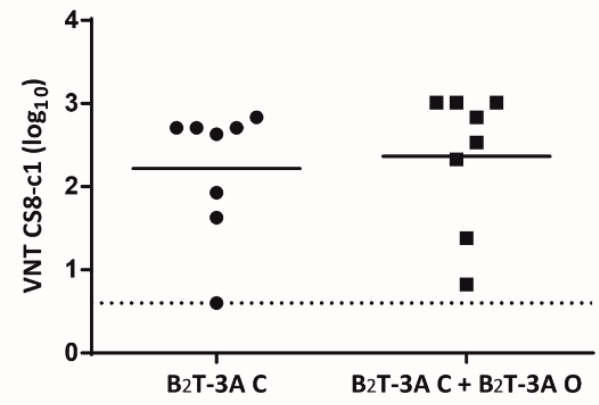

C

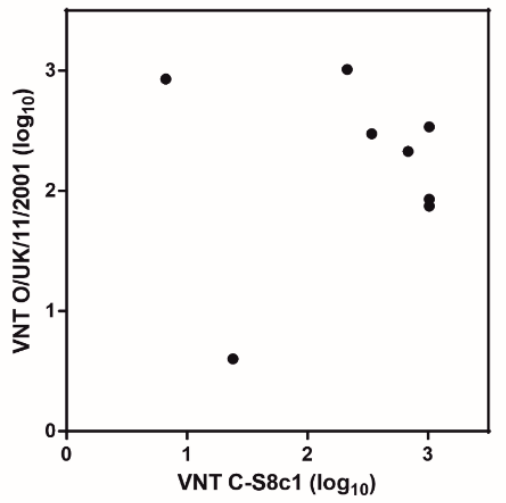

Figure 2. The mixture of two heterotypic $\mathrm{B}_{2} \mathrm{~T}-3 \mathrm{~A}$ constructs elicited similar levels of neutralizing antibodies against Type $\mathrm{C}$ and Type $\mathrm{O}$ FMDVs. Neutralizing antibody titers in sera samples on day $40 \mathrm{pi}$ from mice immunized twice (on days 0 and 21) with an equimolar mixture of $\mathrm{B}_{2} \mathrm{~T}-3 \mathrm{~A}-\mathrm{O}+\mathrm{B}_{2} \mathrm{~T}-3 \mathrm{~A}-\mathrm{C}$ or with $\mathrm{B}_{2} \mathrm{~T}-3 \mathrm{~A}-\mathrm{C}$ or $\mathrm{B}_{2} \mathrm{~T}-3 \mathrm{~A}-\mathrm{O}$ against Type O FMDV $(\mathrm{O} / \mathrm{UK} / 11 / 2001$ isolate) (A) and Type C FMDV (C-S8 isolate) (B). (C) To measure the relationship between antibody titers to serotypes $\mathrm{C}$ and $\mathrm{O}$ in each animal, Pearson's correlation coefficient $(r)$ was calculated: $r=0.07$. Each point represents the mean of a triplicate assay of each animal $(n=8)$. Values are expressed as the reciprocal $\log _{10}$ of the serum dilution that neutralized $100 \mathrm{TCID}_{50}$ of each FMDV.

Homologous neutralization assays were used to determine the capacity of sera from Groups ii and iii above to neutralize C-S8c1 or O/UK/11/2001, respectively. In parallel, neutralization by sera from group $\mathrm{i}\left(\mathrm{B}_{2} \mathrm{~T}-3 \mathrm{~A}\right.$ mixture) was analyzed. In this experiment, no VNT were observed on day 21 pi (data not shown). When the capacity to neutralize type O FMDV was observed (day $40 \mathrm{pi}$ ), similar VNT titers were noticed in mice immunized with $\mathrm{B}_{2} \mathrm{~T}-3 \mathrm{~A}-\mathrm{O}$ (group iii) or the $\mathrm{B}_{2} \mathrm{~T}-3 \mathrm{~A}$ mixture (group i) $\left(2.1 \pm 0.8\right.$ vs. $\left.2.2 \pm 0.8 \log _{10}\right)$ (Figure 2A). Likewise, animals in group ii (given $\mathrm{B}_{2} \mathrm{~T}-3 \mathrm{~A}-\mathrm{C}$ ) produced type $\mathrm{C}$ CS8-c1 VNTs similar to those in the $\mathrm{B}_{2} \mathrm{~T}-3 \mathrm{~A}$ mixture (group i) $\left(2.2 \pm 0.8\right.$ vs. $\left.2.4 \pm 0.8 \log _{10}\right)$ (Figure $2 \mathrm{~B}$ ). When the neutralizing activity against both viruses was compared, six out of eight animals $(75 \%)$ showed high and similar titers against both serotypes, although the correlation was not significant $(p>0.5)$ (Figure 2C). Pearson's correlation coefficient $(r=0.07)$ between titers to serotypes $\mathrm{C}$ and $\mathrm{O}$ in each animal suggested a similar response. 
Early studies on the immunogenicity of FMDV peptide vaccines showed that linear peptides encompassing B- and/or T-cell epitopes elicited levels of protection that were insufficient for their potential commercial application $[9,21,22]$. This limitation has been addressed by various improvement strategies, including optimization of the B- and T-cell peptides [13,23-26] and epitope multimerization [12] achieved through the use of molecular platforms, such as that used in this study, $\mathrm{B}_{2} \mathrm{~T}$, in which B- and T-cell epitopes-the latter was selected as being widely recognized by farm pigs [27] — were jointly and multiply displayed [28]. Indeed, the protection afforded to pigs by $B_{2} T$ vaccines has been shown to be superior to that of other molecules also incorporating the B-cell peptide in $\mathrm{B}_{2} \mathrm{~T}$ (the G-H loop in VP1) (reviewed in [10]). Here, we have further characterized the properties of $B_{2} T$ dendrimer vaccines that are relevant for its use as a field FMD vaccine.

Implementation of efficient vaccination campaigns against FMD requires the use of inactivated viruses that are capable of eliciting protective responses against circulating and emerging FMDVs, which is achieved by including serotype-specific vaccine isolates in vaccine formulations. Thus, because of the wide antigenic range presented by FMDV, an optimal vaccine needs to protect against a wide FMDV spectrum. This is particularly the case for vaccines against type $\mathrm{O}$ viruses, which are responsible for major outbreaks in epidemic countries [29]. Initial experiments with lineal peptides indicated that the nAbs elicited were able to neutralize not only the homologous virus, whose sequence was that of the VP1 GH-loop they contained, but also heterologous FMDV isolates [30]. Here, we provide evidence that mice immunized with a non-covalent mixture of $\mathrm{B}_{2} \mathrm{~T}-3 \mathrm{~A}$ dendrimers containing the B-cell epitopes of FMDV types $\mathrm{O}$ and $\mathrm{C}$ induced similarly high nAb levels against both serotypes, opening the way for a multivalent vaccine platform against a variety of serologically different FMDVs. In addition, we showed that B- and T-cell epitopes need to be tethered to a single molecular platform for successful T-cell help, leading to efficient $\mathrm{nAb}$ induction in mice.

Overall, these findings are relevant for the design of vaccine strategies based on Band T-cell epitope combinations against different FMDVs.

\section{Conclusions}

Our data support the need for a single molecular platform to efficiently present the $\mathrm{B}$ - and T-cell epitopes included in $\mathrm{B}_{2} \mathrm{~T}$ dendrimers, as well as the potential of noncovalent mixtures of $\mathrm{B}_{2} \mathrm{~T}-3 \mathrm{As}$ to induce potent anti-FMDV antibodies against viruses from two different serotypes, which opens the possibility of developing a feasible vaccine platform against a broad spectrum of serologically different FMDVs.

Author Contributions: F.S., E.B., D.A., R.C.-A., P.d.L. and S.D. conceived and designed the experiments. R.C.-A., P.d.L., E.T., S.D., M.F. and M.J.B. performed the experiments. R.C.-A., P.d.L., E.B., D.A. and F.S. analyzed the data and wrote the manuscript. All authors have read and agreed to the published version of the manuscript.

Funding: This research was funded by the Spanish Ministry of Science, Innovation and Universities (grants AGL2014-48923-C2 and AGL2017-84097-C2-2-R (to D.A. and F.S), and PID2019-107145RB100 (to E.B.)), as well as by Comunidad de Madrid co-financed ECFEDER funds (S2013/ABI-350 2906-PLATESA and P2018/BAA-4370 to F.S. and E.B.), and by Generalitat de Catalunya (2009SGR492 to D.A.). Work at Centro de Biología Molecular "Severo Ochoa" and at UPF was supported by the Fundación Ramón Areces and by the Maria de Maeztu Program of the Spanish Ministry of Science, Innovation and Universities, respectively. M.F. and R.C.-A. were holders of a PhD fellowship from the Spanish Ministry of Science, Innovation and Universities.

Institutional Review Board Statement: Experimental procedures were conducted in accordance with protocols approved by the CSIC Committees on Ethical and Animal Welfare and by the National Committee on Ethics and Animal Welfare (PROEX 034/15).

Data Availability Statement: We did not send data to anay database.

Acknowledgments: We thank the staff of the CBMSO and the INIA animal facilities for their assistance. 
Conflicts of Interest: The authors declare no conflict of interest.

\section{References}

1. Knight-Jones, T.J.; Rushton, J. The economic impacts of foot and mouth disease-What are they, how big are they and where do they occur? Prev. Veter Med. 2013, 112, 161-173. [CrossRef]

2. Pereira, H.G. Virus Diseases of Hoof Animals; Academic Press: London, UK, 1981; Volume 2.

3. Rweyemamu, M.; Roeder, P.; Mackay, D.; Sumption, K.; Brownlie, J.; Leforban, Y. Planning for the Progressive Control of Foot-and-Mouth Disease Worldwide. Transbound. Emerg. Dis. 2008, 55, 73-87. [CrossRef]

4. Parida, S. Vaccination against foot-and-mouth disease virus: Strategies and effectiveness. Expert Rev. Vaccines 2009, 8, 347-365. [CrossRef] [PubMed]

5. Smitsaart, E.N.; Bergmann, I.E. Current inactivated FMD vaccines. In Foot-and-Mouth Disease Virus. Current Reasearch and Emmerging Trends; Sobrino, F., Domingo, E., Eds.; Caister Academic Press: Norfolk, UK, 2017.

6. Grubman, M.J.; Baxt, B. Foot-and-Mouth Disease. Clin. Microbiol. Rev. 2004, 17, 465-493. [CrossRef] [PubMed]

7. Robinson, L.; Knight-Jones, T.J.D.; Charleston, B.; Rodriguez, L.L.; Gay, C.; Sumption, K.J.; Vosloo, W. Global Foot-and-Mouth Disease Research Update and Gap Analysis: 3-Vaccines. Transbound. Emerg. Dis. 2016, 63 (Suppl. 1), 30-41. [CrossRef]

8. Blanco, E.; Guerra, B.; de la Torre, B.G.; Defaus, S.; Dekker, A.; Andreu, D.; Sobrino, F. Full protection of swine against foot-and-mouth disease by a bivalent B-cell epitope dendrimer peptide. Antivir. Res. 2016, 129, 74-80. [CrossRef]

9. Taboga, O.; Tami, C.; Carrillo, E.; Núñez, J.I.; Rodríguez, A.; Saíz, J.C.; Blanco, E.; Valero, M.L.; Roig, X.; Camarero, J.A.; et al. A large-scale evaluation of peptide vaccines against foot-and-mouth disease: Lack of solid protection in cattle and isolation of escape mutants. J. Virol. 1997, 71, 2606-2614. [CrossRef]

10. Forner, M.; Cañas-Arranz, R.; Defaus, S.; de León, P.; Rodríguez-Pulido, M.; Ganges, L.; Blanco, E.; Sobrino, F.; Andreu, D. Peptide-Based Vaccines: Foot-and-Mouth Disease Virus, a Paradigm in Animal Health. Vaccines 2021, 9, 477. [CrossRef] [PubMed]

11. Blanco, E.; Garcia-Briones, M.; Sanz-Parra, A.; Gomes, P.; de Oliveira, E.; Valero, M.L.; Andreu, D.; Ley, V.; Sobrino, F. Identification of T-Cell Epitopes in Nonstructural Proteins of Foot-and-Mouth Disease Virus. J. Virol. 2001, 75, 3164-3174. [CrossRef]

12. Lee, H.-B.; Piao, D.-C.; Lee, J.-Y.; Choi, J.-Y.; Bok, J.-D.; Cho, C.-S.; Kang, S.-K.; Choi, Y.-J. Artificially designed recombinant protein composed of multiple epitopes of foot-and-mouth disease virus as a vaccine candidate. Microb. Cell Factories 2017, 16, 33. [CrossRef]

13. Zhang, Z.; Pan, L.; Ding, Y.; Zhou, P.; Lv, J.; Chen, H.; Fang, Y.; Liu, X.; Chang, H.; Zhang, J.; et al. Efficacy of synthetic peptide candidate vaccines against serotype-A foot-and-mouth disease virus in cattle. Appl. Microbiol. Biotechnol. 2014, 99, 1389-1398. [CrossRef]

14. Janeway, C.A.; Travers, P.; Walport, M.; Shlomchik, M.J. Immunology: The Immune System in Health and Disease, 6th ed.; Garland Science Publishing: New York, NY, USA, 2005.

15. Russell, S.M.; Liew, F.Y. T cells primed by influenza virion internal components can cooperate in the antibody response to haemagglutinin. Nature 1979, 280, 147-148. [CrossRef]

16. Yin, L.; Calvo-Calle, J.M.; Cruz, J.; Newman, F.K.; Frey, S.E.; Ennis, F.A.; Stern, L.J. CD4+ T Cells Provide Intermolecular Help to Generate Robust Antibody Responses in Vaccinia Virus-Vaccinated Humans. J. Immunol. 2013, 190, 6023-6033. [CrossRef]

17. Cubillos, C.; de la Torre, B.G.; Jakab, A.; Clementi, G.; Borras, E.; Bárcena, J.; Andreu, D.; Sobrino, F.; Blanco, E. Enhanced mucosal immunoglobulin a response and solid protection against foot-and-mouth disease virus challenge induced by a novel dendrimeric peptide. J. Virol. 2008, 82, 7223-7230. [CrossRef] [PubMed]

18. Monsó, M.; de la Torre, B.G.; Blanco, E.; Moreno, N.; Andreu, D. Influence of Conjugation Chemistry and B Epitope Orientation on the Immune Response of Branched Peptide Antigens. Bioconjugate Chem. 2013, 24, 578-585. [CrossRef]

19. Sobrino, F.; Dávila, M.; Ortin, J.; Domingo, E. Multiple genetic variants arise in the course of replication of foot-and-mouth disease virus in cell culture. Virology 1983, 128, 310-318. [CrossRef]

20. Blanco, E.; Cubillos-Zapata, C.; Moreno, N.; Barcena, J.; de la Torre, B.G.; Andreu, D.; Sobrino, F. B Epitope Multiplicity and B/T Epitope Orientation Influence Immunogenicity of Foot-and-Mouth Disease Peptide Vaccines. Clin. Dev. Immunol. 2013, 2013, 475960. [CrossRef] [PubMed]

21. Pfaff, E.; Mussgay, M.; Böhm, H.; Schulz, G.; Schaller, H. Antibodies against a preselected peptide recognize and neutralize foot and mouth disease virus. EMBO J. 1982, 1, 869-874. [CrossRef] [PubMed]

22. Bittle, J.L.; Houghten, R.A.; Alexander, H.; Shinnick, T.M.; Sutcliffe, J.G.; Lerner, R.A.; Rowlands, D.J.; Brown, F. Protection against foot-and-mouth disease by immunization with a chemically synthesized peptide predicted from the viral nucleotide sequence. Nature 1982, 298, 30-33. [CrossRef] [PubMed]

23. Collen, T.; DiMarchi, R.; Doel, T.R. A T cell epitope in VP1 of foot-and-mouth disease virus is immunodominant for vaccinated cattle. J. Immunol. 1991, 146, 479-755.

24. Glass, E.; Oliver, R.A.; Collen, T.; Doel, T.R.; DiMarchi, R.; Spooner, R.L. MHC class II restricted recognition of FMDV peptides by bovine T cells. Immunol. 1991, 74, 594-599.

25. Wang, C.Y.; Chang, T.Y.; Walfield, A.M.; Ye, J.; Shen, M.; Chen, S.P.; Li, M.C.; Lin, Y.L.; Jong, M.H.; Yang, P.C.; et al. Effective synthetic peptide vaccine for foot-and-mouth disease in swine. Vaccine 2002, 20, 2603-2610. [CrossRef] 
26. Cañas-Arranz, R.; De León, P.; Forner, M.; Defaus, S.; Bustos, M.J.; Torres, E.; Andreu, D.; Blanco, E.; Sobrino, F. Immunogenicity of a Dendrimer B2T Peptide Harboring a T-Cell Epitope from FMDV Non-structural Protein 3D. Front. Veter Sci. 2020, 7, 498. [CrossRef]

27. De León, P.; Cañas-Arranz, R.; Saez, Y.; Forner, M.; Defaus, S.; Cuadra, D.; Bustos, M.J.; Torres, E.; Andreu, D.; Blanco, E.; et al. Association of Porcine Swine Leukocyte Antigen (SLA) Haplotypes with B- and T-Cell Immune Response to Foot-and-Mouth Disease Virus (FMDV) Peptides. Vaccines 2020, 8, 513. [CrossRef] [PubMed]

28. Tam, J.P. Synthetic peptide vaccine design: Synthesis and properties of a high-density multiple antigenic peptide system. Proc. Natl. Acad. Sci. USA 1988, 85, 5409-5413. [CrossRef]

29. Knowles, N.; Samuel, A. Molecular epidemiology of foot-and-mouth disease virus. Virus Res. 2003, 91, 65-80. [CrossRef]

30. Parry, N.R.; Ouldridge, E.J.; Barnett, P.V.; Clarke, B.E.; Francis, M.J.; Fox, J.D.; Rowlands, D.J.; Brown, F. Serological Prospects for Peptide Vaccines against Foot-and-Mouth Disease Virus. J. Gen. Virol. 1989, 70 Pt 11, 2919-2930. [CrossRef] 